\title{
FALL 2017
}

\section{The}

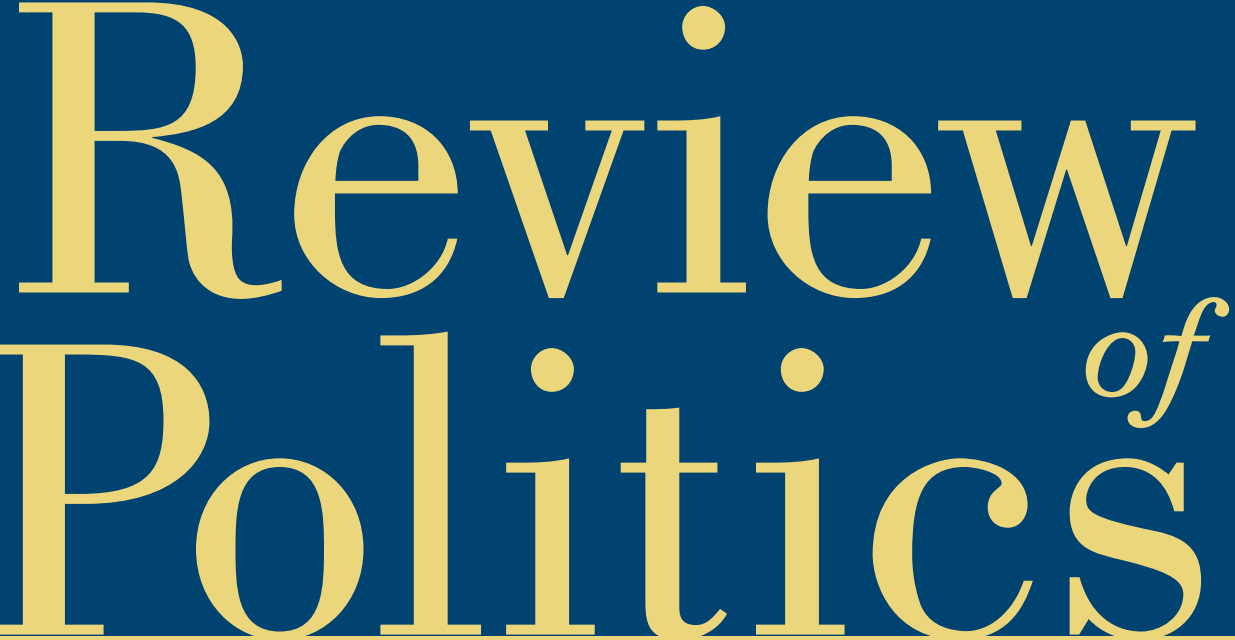

"Dennis WM Moran: In Appreciation and Gratitude"

ARTICLES

Mera J. Flaumenhaft, "Romeo and Juliet for Grownups"

Gregory M. Collins, "Edmund Burke on the Question of Commercial Intercourse in the Eighteenth Century"

Robin Douglass, "Morality and Sociability in Society: Smith, Rousseau-and Mandeville"

John Patrick Coby, “America's Machiavellian: Gouverneur Morris at the Constitutional Convention"

Gianna Englert, "The Idea of Rights': Tocqueville on the Social Question" Review Essay: Ruth Abbey, "On Friendship" 


\title{
THE REVIEW OF POLITICS
}

\author{
Editor \\ CATHERINE H. ZUCKERT \\ Executive Associate Editor \\ DENNIS WM MORAN \\ Book Review Editor \\ SUSAN COLLINS
}

Editorial Board

\author{
Ruth Abbey \\ University of Notre Dame \\ Shlomo Avineri \\ Hebrew University of \\ Jerusalem \\ Barry Cooper \\ University of Calgary \\ Fred Dallmayr \\ University of Notre Dame \\ John Dunn \\ Cambridge University \\ Elizabeth Frazer \\ University of Oxford \\ Michael A. Gillespie \\ Duke University \\ Leslie Goldstein \\ University of Delaware \\ Russell Hittinger \\ University of Tulsa \\ Ramin Jahanbegloo \\ York University \\ Xiaofeng Liu \\ Renmin University of China
}

Pierre Manent

L'Ecole des Hautes Etudes en

sciences sociales

Harvey C. Mansfield

Harvard University

Mary Nichols

Baylor University

Daniel Philpott

University of Notre Dame

Arlene Saxonhouse

University of Michigan

William E. Scheuerman

Indiana University, Bloomington

John T. Scott

University of California, Davis

Steven B. Smith

Yale University

Peter Steinberger

Reed College

Vickie Sullivan

Tufts University

Jean M. Yarbrough

Bowdoin College

\section{Copyeditor: LES HARRIS}

Editorial Interns: Katherine Bermingham and Jordan Dorney Administrative Assistant: Kelli Brown

\section{Former Editors}

\begin{abstract}
Waldemar Gurian
M.A. Fitzsimons

Thomas Stritch
\end{abstract}

\author{
Frederick J. Crosson \\ Donald P. Kommers \\ Walter Nicgorski
}

The Review of Politics publishes primarily philosophical and historical studies of politics, especially those in political theory and American political thought. The journal also includes thoughtful scholarly reflections on all aspects of politics-laws, and institutions, international relations, comparative politics-as well as literary reflections on politics or political interpretations of literature. 


\section{TABLE OF CONTENTS FALL 2017}

Vol. 79

Fall 2017

No. 4

Catherine H. Zuckert

Dennis WM Moran: In Appreciation and Gratitude . . . . . 541

Mera J. Flaumenhaft

Romeo and Juliet for Grownups . . . . . . . . . . . . 545

Gregory M. Collins

Edmund Burke on the Question of Commercial

Intercourse in the Eighteenth Century . . . . . . . . . 565

Robin Douglass

Morality and Sociability in Commercial Society:

Smith, Rousseau - and Mandeville . . . . . . . . . . . . . . 597

John Patrick Coby

America's Machiavellian: Gouverneur Morris at the

Constitutional Convention . . . . . . . . . . . . . . 621

Gianna Englert

"The Idea of Rights": Tocqueville on The Social Question . . . 649

Symposium:

Joshua L. Cherniss, Teresa M. Bejan, Samuel Goldman,

Susan Meld Shell, and Ryan Patrick Hanley on

Steven B. Smith's Modernity and Its Discontents,

with response by Steven B. Smith

Review Essay:

Ruth Abbey

On Friendship . . . . . . . . . . . . . . . . . . . 695

Reviews:

Mary P. Nichols

Review of John von Heyking's The Form of Politics: Aristotle and Plato on Friendship . . . . . . . . . . . . . . . . . . . . . . . . . . . . . . .709

Mark Shiffman

Review of Hugh Liebert's Plutarch's Politics: Between

City and Empire .

Michael Mosher

Review of Iain Hampsher-Monk's Concepts and Reason in

Political Theory. 
Michael Mosher

Review of Richard Tuck's The Sleeping Sovereign: The Invention of Modern Democracy . . . . . . . . . . . . . . . . . . . . . . . . . . . .719

Denise Schaeffer

Review of John M. Warner's Rousseau and the Problem of Human

Relations.

Onur Ulas Ince

Review of Daniel O'Neill's Edmund Burke and the Conservative Logic of Empire . . . . . . . . . . . . . . . . . . . . . . . . . . . . . .726

Luke Mayville

Review of Richard Alan Ryerson's John Adams's Republic: The One, the Few, and the Many . . . . . . . . . . . . . . . . . . . . . . . . . . . . .729

Andrew E. Busch

Review of Bruce Miroff's Presidents on Political Ground: Leaders in Action and What They Face. . . . . . . . . . . . . . . . . . . . . . .732

Jon A. Shields

Review of Melissa Moschella's To Whom Do Children Belong:

Parental Rights, Civic Education, and Children's Autonomy. . . . . . . . .735

Alan D. Schrift

Review of Gary Shapiro's Nietzsche's Earth: Great Events, Great Politics ...

Uriel Abulof

Review of Bill Kissane's Nations Torn Asunder: The Challenge of

Civil War....

John Schuessler

Review of David A. Baldwin's Power and International Relations:

A Conceptual Approach . . . . . . . . . . . . . . . . . . . . . . . . .743

Niklas Plaetzer

Review of Uriel Abulof's The Mortality and Morality of Nations:

Jews, Afrikaners and French Canadians . . . . . . . . . . . . . . . . .745

David Ganz

Review of Thomas W. Laqueur's The Work of the Dead: A Cultural

History of Mortal Remains . . . . . . . . . . . . . . . . . . . . . . . .748

Michael P. Zuckert

Review of Mark Lilla's The Shipwrecked Mind: On Political Reaction . . . .751

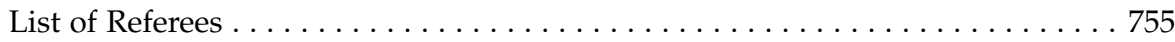

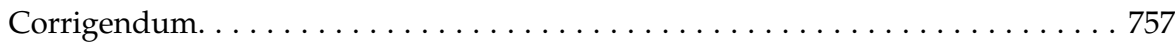


Subscription Information: The Review of Politics (ISSN 0034-6705) is published quarterly in February, May, August and November by Cambridge University Press, One Liberty Plaza, 20th Floor, New York, NY 10006, USA/University Printing House, Shaftesbury Road, Cambridge CB2 8BS, UK for the University of Notre Dame. Annual subscription rates for Volume 79 (2017): Institutional subscription rates, print and online: US $\$ 207.00$ in the USA, Canada, and Mexico; UK $£ 121.00$ + VAT elsewhere. Institutional subscription rates, online only: US $\$ 171.00$ in the USA, Canada, and Mexico; UK £104.00 + VAT elsewhere. Institutional subscription rates, print only: US \$197.00 in the USA, Canada, and Mexico; UK $£ 119.00$ + VAT elsewhere. Individual subscription rates, print only: US $\$ 48.00$ in the USA, Canada, and Mexico; UK $£ 27.00+$ VAT elsewhere. Correspondence concerning subscriptions should be sent to: Cambridge University Press, One Liberty Plaza, 20th Floor, New York, NY 10006, USA for customers in the USA, Canada, or Mexico. Customers elsewhere should contact: Cambridge University Press, University Printing House, Shaftesbury Road, Cambridge CB2 8BS, UK.

Editorial Office: All correspondence concerning submissions and manuscripts under review should be sent to The Review of Politics, University of Notre Dame, 2005 Jenkins Nanovic Halls, Notre Dame, IN 46556-7000. Phone: 574-631-6623. Email: ROP.Editor.1@nd.edu. Website: reviewofpolitics. nd.edu

Abstracting and Indexing Information: Articles in The Review of Politics are indexed in the International Index to Periodicals and the Catholic Periodicals and Literature Index; abstracted in the International Political Science Abstracts; and abstracted and indexed in ABC POL. SCI., Historical Abstracts, Social Science Index (also available in the electronic versions), Book Review Index, and International Bibliography of the Social Sciences.

Copyright (C) 2017 University of Notre Dame. All rights reserved. No part of this publication may be reproduced, in any form or by any means, electronic, photocopy, or otherwise, without permission in writing from Cambridge University Press, Rights and Permissions Manager, One Liberty Plaza, 20th Floor, New York, NY 10006, USA. For further information see http://us.cambridge/org/information/rights/

Periodicals postage paid in New York, NY and additional mailing offices. Postmaster: Send address changes to The Review of Politics, Cambridge University Press, One Liberty Plaza, 20th Floor, New York, NY 10006, USA.

Photocopying information for users in the U.S.A.: the Item-Fee Code for the publication (0034-6705/17 \$9.00 +.10) indicates that copying for internal or personal use beyond that permitted by Sec. 107 or 108 of the U.S. Copyright Law is authorized for users duly registered with the Copyright Clearance Center (CCC) provided that the appropriate remittance of $\$ 9.00$ per article is paid directly to CCC, 222 Rosewood Drive, Danvers, MA 01923. Specific written permission must be obtained for all other copying. 